\title{
The Dynamic Mathematics Software for Teaching Variance
}

\author{
$\mathrm{Li} \mathrm{Li}^{1, \text { a) }}$, Haiming Tang ${ }^{2}$ \\ ${ }^{1}$ Guangxi Normal University \\ 1 Yanzhong Road, Guilin, Guangxi, China \\ ${ }^{2}$ Yanshan Middle School \\ 342 Yanshan Town, Guilin, Guangxi, China \\ a) $1551586972 @ q q . c o m$
}

\begin{abstract}
In traditional teaching, many teachers often ignore the process of students' knowledge exploration, devote themselves to instilling knowledge to students in a short time, and then adopt the sea of questions tactics. Such teaching is only limited to the stage of telling students what "variance" is and how to use it, and ignores the birth process and meaning of "variance". The purpose of this research is to see the differences in classes that use dynamic mathematics software and traditional classes. The method in this research is descriptive qualitative. The sample in this study was seventh-grade students at one of the junior high schools in China. The content of this research design is the use of dynamic mathematics technology, focusing on the understanding of the concept of efficiency-improving variance, and the form innovation of the course design is design and record before and after optimization-evaluation and analysis before and after optimization. This article mainly takes the concept of teaching variance topic as an example to try to explore the teaching design of optimizing the important and difficult points of mathematics. This study shows that Hawgent dynamic mathematics software makes students get deep learning and makes teaching and learning activities more active. Then the teacher can continue to use Hawgent dynamic mathematics software to make students more active.
\end{abstract}

Keywords: Dynamic Mathematics Software; Hawgent; Variance

\begin{abstract}
Abstrak.
Dalam pembelajaran tradisional, mungkin guru mengabaikan proses explorasi pengetahuan siswa dan cenderung menanamkan pengetahuan kepada siswa dalam waktu singkat, setelah itu mengakhiri dengan memberikan banyak latihan pertanyaan. Cara mengajar seperti itu hanya dapat memberi tahu siswa apa itu "varians" dan bagaimana cara menggunakan rumusnya tetapi mengabaikan proses pencarian konsep dasar "varians" tersebut. Tujuan penelitian ini adalah untuk melihat perbedaan kelas yang menggunakan dynamic mathematics software dan kelas tradisional. Metode pada penelitian ini adalah deskriptif kualitatif. Sampel pada penelitian ini adalah siswa kelas tujuh di salah satu SMP di Tiongkok. Tujuan penelitian ini adalah memanfaatkan teknologi khususnya dynamic mathematics software dalam menerangkan pemahaman konsep dasar varians dan melihat pengaruh sebelum dan sesudah memakai dynamic mathematics software Hawgent pada materi varians. Hasil penelitian ini menunjukkan bahwa dynamic mathematics software membuat siswa mendapatkan pembelajaran yang mendalam dan membuat kegiatan belajar menjadi lebih aktif. Saran untuk guru agar terus mengembangkan media pembelajaran menggunakan teknologi agar dapat meningkatkan minat dan hasil belajar siswa.
\end{abstract}

Kata kunci: Dynamic Mathematics Software; Hawgent; Variance 


\section{INTRODUCTION}

Variance is the content of the second section of Chapter 6 of the Compulsory Education Textbook Hunan Education Edition Mathematics Grade Seven. Before this, students have mastered the statistics describing the degree of data concentration such as mean, mode, and median (Purnama, Wijaya, Dewi, \& Zulfah, 2020). the variance to be learned next is the amount that describes the new shape of the data (Wahyudi, Abadyo, \& Purwanto, 2017). In traditional teaching, many teachers often ignore the process of students' knowledge exploration and devote themselves to instilling knowledge to students in a short period (Dewi, Mediyani, Hidayat, Rohaeti, \& Wijaya, 2019; Wijaya, Ying, Cunhua, \& Zulfah, 2020). Then adopt the sea of questions tactics. Such teaching is only limited to the stage of telling students what "variance" is and how to use it, and ignores the birth process and meaning of "variance". Learning models like this will make students not understand the basic concepts of mathematics. Students may just remember the formula for doing practice questions.

This course designed the discrete degree of the hands-on data input operation experience data and the "rectangular observation window" to achieve the deep integration of number and shape. By asking students how to calculate the deviation of all data from the average? How to compare the degree of fluctuation if the two sets of data have different numbers? Why not describe the sum of absolute deviations? The series of questions are intertwined and guided according to the situation. While highlighting the key points and solving the difficulties, it also accumulates students' experience in basic activities, comprehends the mathematical thinking of "combination of numbers and shapes", and cultivates students' core qualities such as hands-on ability and mathematical modeling.

The Chinese Government (2010-2020) pointed out that pay attention to the application of information technology and realize the deep integration of information technology and curriculum (Aixia, Ying, \& Wijaya, 2020). It can be found that information technology will be integrated into teaching more universally, naturally, and efficiently in the future, especially now in mathematics teaching. With the development of information technology and the Internet, teaching software has become more and more effective and convenient (Wijaya, Jianlan, \& Aditya, 2020).

Hawgent Dynamic Mathematics is a mathematics software independently developed by Guangzhou Hawgent Education Technology Co., Ltd (Wijaya, 2020; Wijaya, Ying, Chotimah, Bernard, Zulfah, \& Astuti, 2020). that integrates dynamic, intuitive, and mathematical features (Cunhua, Ying, Qunzhuang, \& Wijaya, 2019). At the same time, its system comes with a large number of mathematics teaching resources and series of courses, becoming its unique characteristics. It has three characteristics are (1) The operation is more flexible (Suan, Ying, \& 
Wijaya, 2020). (2) The mathematical function is more powerful (Wijaya, Ying, \& Purnama, 2020). (3) Dynamic resources are more abundant.

Hawgent dynamic mathematics software has been used more and more widely in teaching by its powerful mathematics functions, rich curriculum resources, and convenient operating system (Tan, Zou, Wijaya, Suci, \& Dewi, 2020). At the same time, it has played an important role in assisting mathematics teaching. (1) Rich intuitive imagination: Dynamic mathematics technology can be described as a "microscope" or "telescope", which realizes "fine magnification, distant and near vision, abstract and concrete, static and vivid", making it easy to associate or unimaginable content. Imagine intuitively. (2) Strengthen hands-on operation: Hands-on operation is an important way to help discover mathematics. Hawgent Dynamic Mathematics can perform in-depth operations such as dragging and inputting data on mathematical objects, which is convenient for quickly discovering the internal laws of mathematics. (3) Conjecture verification: Mathematical conjecture is an important way to discover mathematics. Polya advocates: "Discover from conjecture, guess from discovery". Hawgent dynamic mathematics technology facilitates the creation of a learning environment that helps conjecture and verifies mathematics. (4) Enhance learning interest (Wijaya, Ying, \& Purnama, 2020), interest is the best teacher. Hawgent dynamic mathematics software can produce novel, magical, fun, interesting, dynamic. Hawgent also can stimulate interest in learning, cultivate good habits, and promote mathematics belief.

In this study, the researcher describes the traditional lesson planning class and experiment class that uses Hawgent dynamic mathematics software. So that the results of this study can see which class is better. Furthermore, the research results can help teachers to prepare lesson planning.

\section{METHOD}

This article adopts the comparative analysis research method. In May 2019, the author taught an experimental class on Variance material at Yanshan Middle School in Guilin, Guangxi, China. Through the teaching of the Concept of Variance in the second volume of the seventh grade (Junior High School) of the Xiangjiao edition. The stages of this research stage are 1)Analyze the fragments of the two different teaching methods from the number of questions, 2) to see the degree of visualization and the degree of thinking activity, 3) to see the conceptual understanding, and knowledge A comparative analysis lesson plan of three aspects of development fit. focusing on analyzing the use of Hawgent dynamic mathematics software to assist the teaching of the concept of variance. supplemented by a series of questions to establish a scaffold, guiding students to think and actively explore the process of occurrence, development, and application of the concept of variance. The questions used in this study can be seen in Figure 1. 
Question: Jack and Rose's shooting training results (unit: ring) are as follows:

Please evaluate the two athletes?

\begin{tabular}{l|l|l|l|l|l|l|l|l|l|l}
\hline frequences & $\mathrm{x}_{1}$ & $\mathrm{x}_{2}$ & $\mathrm{x}_{3}$ & $\mathrm{x}_{4}$ & $\mathrm{x}_{5}$ & $\mathrm{x}_{6}$ & $\mathrm{x}_{7}$ & $\mathrm{x}_{8}$ & $\mathrm{x}_{9}$ & $\mathrm{x}_{10}$ \\
\hline Jack & 8 & 6 & 8 & 8 & 7 & 6 & 6 & 8 & 7 & 6 \\
\hline Rose & 7 & 6 & 7 & 9 & 8 & 6 & 6 & 8 & 4 & 9 \\
\hline
\end{tabular}

Figure 1. Exercise Questions on the Variance Material in this Study

\section{RESULT AND DISCUSSION}

\section{Traditional Class}

First, create a problem situation and collect the results of a certain shooting performance of two students. Ask students to evaluate and judge the shooting performance of the two students through calculation. secondly, give the formula for calculating the variance and briefly explain the meaning of the symbols in the formula; Students "check-in" and bring the data into the formula to calculate the variance; the final summary and induction variance is to describe the statistical significance of a set of data fluctuations and conduct a lot of classroom exercises to consolidate knowledge.

Teacher : Recently, our school began to select students to participate in the city's youth shooting competition. It's a great honor for our class Jack and Rose to enter the finals. Below is the list of their final scores, Jack: 8, 6, 8, 8, 7, 6, 6, 8, 7, 6 and Rose: 7, 6, 7, 9, 8, 6, 6, 8, 4, 9 who should choose to participate in the city competition? Ask students to speak with data through calculations.

Student $\quad:($ Calculating...)

Student $\quad$ I I calculated that their average score is 7 rings, the median score is 7 rings, and the score mode is 6 rings. The grades are equally good, but I still don't know who should I choose.

Teacher : That's right. It seems that average grades cannot help us to judge. Today, let's learn a new statistic-variance. Variance is a description of the degree of fluctuation of a set of data, which can also be said to be the degree of dispersion. We compare the variance of two students. The smaller the variance, the more stable his performance and the better his performance. It is more suitable for participating in the market game.

Student : What is the variance? 
Teacher : Please see the textbook, we use $s^{2}$ to represent the variance. In fact, the whole formula is to calculate the difference between each data and the average and finally find the average. We use it to describe the degree of fluctuation of this group of data.

Student : Wow!

Teacher : Then, please let the students bring these two sets of data into the variance calculation formula to calculate the results. Please share the answers with us later.

Student : The variance of Jack's score is 0.4, and the variance of Rose's score is 2.0, so you should choose Jack.

Teacher : Good. This is the variance we learned today. Please do the class exercises at the back of the textbook.

\section{Experimental Class}

First of all, create a problem situation, collect the shooting results of the two students in the final, ask the students to draw a scatter diagram in the Hawgent dynamic software for comparison after calculation, and compare the fluctuation degree of the two groups of data intuitively but roughly. Naturally, lead students to think about replacing it with a statistical quantity. Then through a series of "question strings" complemented with Hawgent dynamic mathematics, students are guided to derive the calculation formula of variance. In the process of "trial and error", there are "guess", "thinking" and analogy, and "number" and "shape". There are intuitive.

Recently, our school began to select students to participate in the youth shooting competition in the city. I am very honored that Jack and Rose from our class were selected for the finals. Below is a list of their final results. Jack: 8, 6, 8, 8, 7, 6, 6, 8, 7, 6; Rose: 7, 6, 7, 9, 8, 6, 6, 8, 4, 9 who should I choose to participate in the city competition? Ask students to speak with data through calculations.

Student $\quad:($ Calculating...)

Tabel 1. Comparison Table of Statistics Calculated by Students

\begin{tabular}{cccc}
\hline Students & Average & Median & Mode \\
\hline Jack & 7 & 7 & 6 \\
\hline Rose & 7 & 7 & 6 \\
\hline Comparison & Same & Same & same \\
\hline
\end{tabular}

Student $\quad$ I I calculated that their average score is 7 rings, the median score is 7 rings, and the score mode is 6 rings. The grades are equally good, but I still don't know who should I choose.

Teacher : That's right. It seems that we need to find a new standard to evaluate the two players. We all know that the ability to play on the spot is particularly important in the game, the more stable the play, the better. We might as well enter the two sets of results in the Hawgent 
dynamic math software and observe the respective scatter plots to see which player has a stable performance?

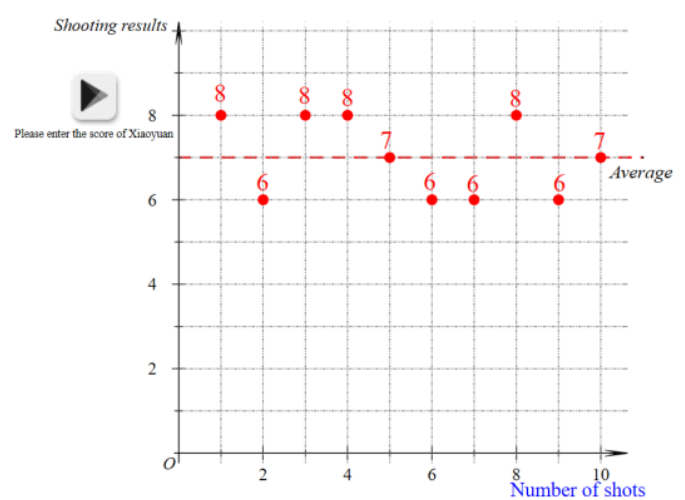

Jack's score

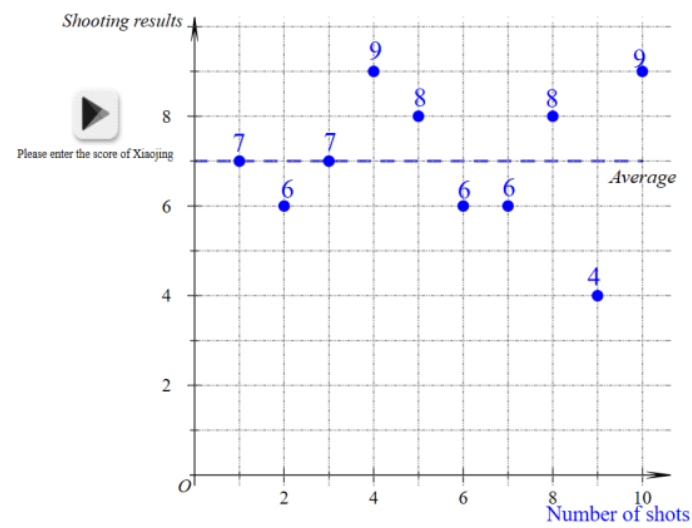

Rose's score

Figure 2. Calculate the Results of the Shot Using Hawgent Dynamic Mathematics Software

Student : Comparing the two scatter plots (figure 2), jack's scores are distributed more densely on both sides of the average, while rose's scores are more scattered on both sides of the average. Therefore, it should be that jack's performance is more stable.

Teacher : Yes. Excellent, very accurate explanation. But if we observe through the scatter plot every time it is not only troublesome but also inaccurate, do you have any good ideas to solve this problem?

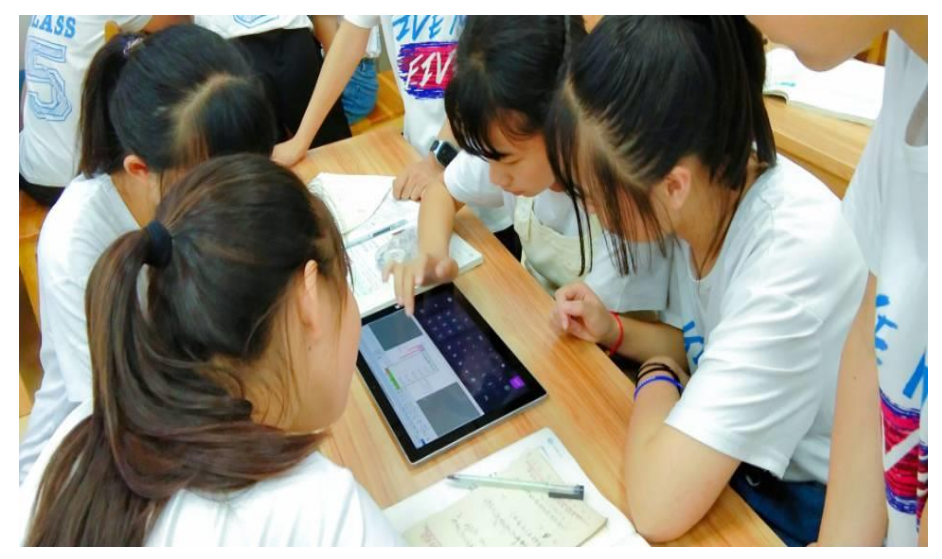

Figure 3. Student Team Work Use Tablet to Explore

Student : If the degree of fluctuation is just a number, you can directly compare the magnitude.

Teacher : The average, mode, and median that we learned earlier use data to describe the degree of concentration of a set of data. Can we imitate it and calculate the degree of fluctuation of this set of data? Use numerical values to describe this degree of dispersion.

Student : How to calculate it? Is there a formula? 
EDUMATIKA: Jurnal Riset Pendidikan Matematika

Teacher : Please think about it. Which quantity in the figure is the benchmark for the fluctuation we are talking about?

Student : Average.

Teacher : Why is it average?

Student : Because the average reflects the concentration of this set of data, it is where this set of data is most concentrated.

Teacher : Well, very good. The deviation of the number in a set of data from the average of this set of data is an important feature of the data, and it reflects the degree of dispersion or fluctuation of a set of data. How to calculate the deviation of each data from the average?

Student : The degree of volatility can be regarded as the distance between each data and the average. How to calculate this distance?

Student : Deviation is to make the difference between this data and the average.

Teacher : How can you calculate the deviation of all data from the average?

Student : Each data and the average are summed after the difference.

Teacher : Correct. Then, please make the difference between these two sets of data and their averages respectively, and then sum them and fill in the table below. What do you find?

Table 2. Statistics of Shooting Results of Jack and Rose

\begin{tabular}{cccccccccccc}
\hline Frequency & $\boldsymbol{x}_{\boldsymbol{1}}$ & $\boldsymbol{x}_{\boldsymbol{2}}$ & $\boldsymbol{x}_{\boldsymbol{3}}$ & $\boldsymbol{x}_{\boldsymbol{4}}$ & $\boldsymbol{x}_{\boldsymbol{5}}$ & $\boldsymbol{x}_{\boldsymbol{6}}$ & $\boldsymbol{x}_{\boldsymbol{7}}$ & $\boldsymbol{x}_{\boldsymbol{8}}$ & $\boldsymbol{x}_{\boldsymbol{9}}$ & $\boldsymbol{x}_{\boldsymbol{1 0}}$ & \\
\hline Jack's score & 8 & 6 & 8 & 8 & 7 & 6 & 6 & 8 & 7 & 6 & \\
\hline Mean difference & 1 & -1 & 1 & 1 & 0 & -1 & -1 & 1 & 0 & -1 & 0 \\
\hline Rose's score & 7 & 6 & 7 & 9 & 8 & 6 & 6 & 8 & 4 & 9 & \\
\hline Mean difference & 0 & -1 & 0 & 2 & 1 & -1 & -1 & 1 & -3 & 2 & 0 \\
\hline
\end{tabular}

Student : It's strange. Rose's performance fluctuates greatly in the scatter chart (table 3), but after doing the difference calculation in this way, the positive and negative cancel each other out, and the values are all 0 .

Teacher : How to solve this positive-negative offset problem?

Student : : Absolute value can be added.

Student : Squaring is fine.

Teacher : Wow, there are so many ideas. Both the absolute value and the square are non-negative. Which one is better? Please try these two methods separately. Are the results consistent with the image results we observed? Which method do you think is better? 
EDUMATIKA: Jurnal Riset Pendidikan Matematika

e-ISSN 2620-8911

Volume 3, Nomor 2, November 2020

p-ISSN 2620-8903

Table 3. Statistics of the Absolute Value of the Average Difference and the Square of the Average Difference in the Shooting Results of Jack and Rose

\begin{tabular}{|c|c|c|c|c|c|c|c|c|c|c|c|c|}
\hline & Frequency & $x_{1}$ & $x_{2}$ & $x_{3}$ & $x_{4}$ & $x_{5}$ & $x_{6}$ & $x_{7}$ & $x_{8}$ & $x_{9}$ & $x_{10}$ & Total \\
\hline \multirow{3}{*}{ Jack } & Jack's score & 8 & 6 & 8 & 8 & 7 & 6 & 6 & 8 & 7 & 6 & \\
\hline & $\begin{array}{c}\text { Absolute mean } \\
\text { difference }\end{array}$ & 1 & 1 & 1 & 1 & 0 & 1 & 1 & 1 & 0 & 1 & 8 \\
\hline & Equal square & 1 & 1 & 1 & 1 & 0 & 1 & 1 & 1 & 0 & 1 & 8 \\
\hline \multirow{3}{*}{ Rose } & Rose's score & 7 & 6 & 7 & 9 & 8 & 6 & 6 & 8 & 4 & 9 & \\
\hline & $\begin{array}{c}\text { Absolute mean } \\
\text { difference }\end{array}$ & 0 & 1 & 0 & 2 & 1 & 1 & 1 & 1 & 3 & 2 & 12 \\
\hline & Equal square & 0 & 1 & 0 & 4 & 1 & 1 & 1 & 1 & 9 & 4 & 22 \\
\hline
\end{tabular}

Teacher : Is here to sell a key point. May wish to ask students to enter the following two sets of data in Hawgent 8, 4, 6, 4, 8, 7, 9, 6, 5, 3. What did you find?

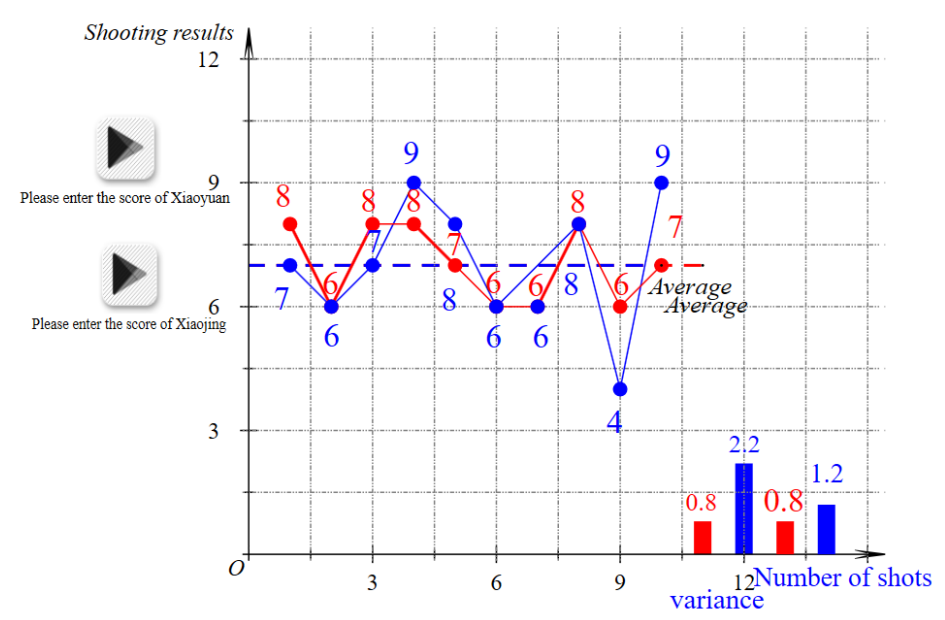

Figure 4. Visualized Variance Graph of Shooting Results of Jack and Rose using Hawgent.

Student : They are all the same (Figure 4), but the absolute value calculation is relatively simple.

All students : The sum of the absolute value of the difference between each data of the two sets of data and the average is equal, but the square of the difference between each data and the average is different. After the square, the larger the number and the smaller the decimal, the more obvious the distinction.

Teacher : The teacher has another doubt: If the two sets of data have different numbers, is it feasible to compare the sizes by summation? What is your solution?

Table 4. Shooting Statistics in the Absence of Value

\begin{tabular}{|c|c|c|c|c|c|c|c|c|c|c|c|c|}
\hline & Frequency & $x_{1}$ & $x_{2}$ & $x_{3}$ & $x_{4}$ & $x_{5}$ & $x_{6}$ & $x_{7}$ & $x_{8}$ & $x_{9}$ & $x_{10}$ & Total \\
\hline \multirow[t]{2}{*}{ Jack } & Score & 8 & 0 & 8 & 8 & 0 & 6 & 6 & 0 & 7 & 6 & \\
\hline & Equal Square & & & & & & & & & & & \\
\hline \multirow[t]{2}{*}{ Rose } & Score & 7 & 6 & 7 & 9 & 8 & 6 & 6 & 8 & 4 & 9 & \\
\hline & Equal square & & & & & & & & & & & \\
\hline
\end{tabular}


Student $\quad$ : This is simple. In order to eliminate the difference in the number of data, we just take the average.

Teacher : Perfect! Then we take the average of the square of the mean deviation, and this quantity is named variance. We use $s^{2}$ to represent the variance. In fact, the whole formula is to calculate the difference between each data and the average, then square, and finally find the average. We use it to describe the degree of fluctuation of this set of data.

\section{Evaluation and Analysis Before and After Optimization}

This creative course integrates Hawgent dynamic technology to reproduce the birth process of the variance formula, and infiltrate mathematical ideas and core qualities such as "combination of number and shape", "mathematical modeling", and "data analysis" in the derivation process. Breakthrough the difficult points of mathematics, allowing students to accumulate experience in basic mathematics activities in "hands-on operation" and "thinking and expression". Improve students' core literacy in mathematical subjects such as "mathematical modeling" and "data analysis". Compared with the original teaching design, the optimized teaching design has the following characteristics.

First, pay attention to the deep integration of information technology and mathematics classrooms. The original instructional design directly gives the formula for calculating the variance, and then uses the "Question Sea Tactics" to let students learn the formula and calculate skillfully. This kind of teaching method is very efficient on the surface, but in fact, it does not conform to the students' cognitive laws. It ignores the process of deriving calculation formulas and the generation and development of statistical concepts. Students do not understand the formulas, and it is not conducive to The formation of students' statistical concepts. Optimized teaching design. First of all, a button for manually inputting two sets of data in the same coordinate system is designed for students to compare the horizontal and vertical data and compare the relationship between each data in this set of data and the average value vertically. Horizontally compare statistics such as the average value and variance of the two sets of data, more intuitively understand the degree of fluctuation or dispersion, and manually operate it to improve students' interest in learning and awareness of participation. Secondly, give full play to the spiral combination function of number and shape, design "variance rectangular observation window" and "deviation absolute value and rectangular observation window", through the two-pronged approach of rectangular area change and accurate measurement data, the degree of subtle fluctuations can not be sensed. Quantify and visualize, improve classroom efficiency, and deepen students' understanding of the degree of dispersion. 
The optimized teaching design fully considers the impact of information technology on the content and methods of mathematics learning and regards modern information technology as a powerful tool for students to learn mathematics and solve problems (Listiawan, Purwanto, As'Ari, \& Muksar, 2018), effectively improve the methods of teaching and learning, and promote students' willingness and the possibility to invest in exploration Go to mathematics activities (Wijaya, Purnama, \& Tanuwijaya, 2020).

Secondly, skillfully use "question strings" to dig deeper into students' thinking. The original teaching design takes teachers as the main body, directly instilling ready-made knowledge, causing students to "indigestion", only staying in simple and repetitive mechanical memory, enlightenment without problems, and collision of thinking. The optimized teaching design focuses on heuristic teaching, and the "question string" has been changed from purely imparting knowledge to guided learning. For example, the question string-"Which amount of fluctuation is based on the figure?" "The degree of fluctuation? That is, as the distance between each data and the average, how to calculate this distance?" "How to solve this positive and negative offset problem?" "If the two sets of data have different numbers, compare the sizes by summing, it is feasible Do you have any way to solve it?" Throughout the entire teaching design, interlocking and guiding the situation. In short, under the effective guidance of teachers, the active participation of students, and the technical support of dynamic mathematics, the optimized instructional design integrates students' cognition and emotion, body, and environment, and promotes students' understanding of the nature of mathematics while accumulating mathematics. Basic activity experience, comprehend the basic ideas of mathematics and enhance the positive emotional experience of mathematics, to teach people how to fish and how to fish and desire.

\section{CONCLUSION}

By comparing the two teaching fragments of The Concept of Variance, comparing the teaching fragments before and after optimization from the two aspects of the in-depth blending degree comparison between information technology and mathematics classroom and students' thinking degree comparison. the results are obtained Hawgent dynamic mathematics software has played a positive role in cultivating students' core literacy of mathematics and improving classroom teaching than a traditional class. Teachers can continue to use dynamic mathematics software to keep the classroom atmosphere active, where students discover the basic concepts of the material by themselves

\section{REFERENCES}

Aixia, W., Ying, Z., \& Wijaya, T. T. (2020). The current situation and prospect of study quality evaluation research in china in the last 10 years. EDUKATIF: JURNAL ILMU PENDIDIKAN, 2(1), 101-112. 
Cunhua, L., Ying, Z., Qunzhuang, O., \& Wijaya, T. T. (2019). Mathematics course design based on six questions cognitive theory using hawgent dynamic mathematic. Journal On Education, 02(01), 36-44.

Dewi, D. P., Mediyani, D., Hidayat, W., Rohaeti, E. E., \& Wijaya, T. T. (2019). Analisis Kemampuan Berpikir Kritis Matematis Siswa Smp Pada Materi Lingkaran Dan Bangun Ruang Sisi Datar. JPMI (Jurnal Pembelajaran Matematika Inovatif), 2(6), 371. https://doi.org/10.22460/jpmi.v2i6.p371-378

Listiawan, T., Purwanto, P., As'Ari, A. R., \& Muksar, M. (2018). Mathematics Teachers Technological Content Knowledge (TCK) in using Dynamic Geometry Software. Journal of Physics: Conference Series, 1114(1). https://doi.org/10.1088/1742-6596/1114/1/012121

Purnama, A., Wijaya, T. T., Dewi, S. N., \& Zulfah, Z. (2020). Analisis Buku Siswa Matematika SMA dari Indonesia dan China Pada Materi Peluang dan Statistik. Jurnal Cendekia: Jurnal .... Retrieved from https://j-cup.org/index.php/cendekia/article/view/305

Suan, L., Ying, Z., \& Wijaya, T. T. (2020). Using hawgent dynamic mathematics software in teaching arithmetic operation. International Journal of Education and Learning, 2(1), $25-31$. https://doi.org/10.31763/ijele.v2i1.97

Tan, S., Zou, L., Wijaya, T. T., Suci, N., \& Dewi, S. (2020). Improving student creative thinking ability with problem based learning approach using hawgent. Journal on Education, 02(04), 303-312.

Wahyudi, W., Abadyo, A., \& Purwanto, P. (2017). Analisis Kesalahan Mahasiswa Dalam Menurunkan SifatSifat Variansi Dan Simpangan Baku. JURNAL SILOGISME: Kajian Ilmu Matematika Dan Pembelajarannya, 2(1), 39. https://doi.org/10.24269/js.v2i1.520

Wijaya, T.T., Ying, Z., \& Purnama, A. (2020). Using Hawgent dynamic mathematics software in teaching trigonometry. International Journal of Emerging Technologies in Learning, 15(10). https://doi.org/10.3991/ijet.v15i10.13099

Wijaya, T. T. (2020). How chinese students learn mathematics during the coronavirus pandemic. International Journal of Educational Research and Innovation (IJERI), 15, 1-16. https://doi.org/https://doi.org/10.46661/ijeri.4950

Wijaya, T. T., Jianlan, T., \& Aditya, P. (2020). Developing an Interactive Mathematical Learning Media Based on the TPACK Framework Using the Hawgent Dynamic Mathematics Software. Emerging Technologies in Computing, 318-328. https://doi.org/10.1007/978-3-030-60036-5

Wijaya, T. T., Purnama, A., \& Tanuwijaya, H. (2020). Pengembangan Media Pembelajaran Berdasarkan Konsep Tpack pada Materi Garis dan Sudut Menggunakan Hawgent Dynamic Mathematics Software. JPMI - Jurnal Pembelajaran Matematika Inovatif, 3(3), $205-214$. https://doi.org/10.22460/jpmi.v1i3.205-214

Wijaya, T. T., Ying, Z., Chotimah, S., Bernard, M., Zulfah, Z., \& Astuti, A. (2020). Hawgent dynamic mathematic software as mathematics learning media for teaching quadratic functions. Journal of Physics: Conference Series, 1592(1). https://doi.org/10.1088/1742-6596/1592/1/012079

Wijaya, T. T., Ying, Z., Cunhua, L., \& Zulfah. (2020). Using VBA learning media to improve students ' mathematical understanding ability. Journal On Education, 02(02), 245-254.

Wijaya, T. T., Ying, Z., \& Purnama, A. (2020). The empirical research of hawgent dynamic mathematics technology integrated into teaching. Journal Cendekia: Jurnal Pendidikan Matematika, 04(01), 144150. 